\title{
$\beta$-Amyloid Peptide at Sublethal Concentrations Downregulates Brain-Derived Neurotrophic Factor Functions in Cultured Cortical Neurons
}

\author{
Liqi Tong, Robert Balazs, Phillip L. Thornton, and Carl W. Cotman \\ Institute for Brain Aging and Dementia, University of California Irvine, Irvine, California 92697-4540
}

\begin{abstract}
The accumulation of $\beta$-amyloid $(\mathrm{A} \beta)$ is one of the etiological factors in Alzheimer's disease (AD). It has been assumed that the underlying mechanism involves a critical role of $\mathrm{A} \beta$-induced neurodegeneration. However, low levels of $\mathrm{A} \beta$, such as will accumulate during the course of the disease, may interfere with neuronal function via mechanisms other than those involving neurodegeneration. We have been testing, therefore, the hypothesis that $\mathrm{A} \beta$ at levels insufficient to cause degeneration (sublethal) may interfere with critical signal transduction processes. In cultured cortical neurons $\mathrm{A} \beta$ at sublethal concentrations interferes with the brain-derived neurotrophic factor (BDNF)-induced activation of the Ras-mitogen-activated protein kinase/extracellular signal-regulated protein kinase (ERK) and phosphatidylinositol 3-kinase (PI3-K)/Akt pathways. The effect of sublethal $\mathrm{A} \beta_{1-42}$ on BDNF signaling results in the suppression of the activation of critical transcription factor cAMP response element-binding protein and Elk-1 and cAMP response element-mediated and serum response element-mediated transcription. The site of interference with the Ras/ERK and PI3-K/Akt signaling is downstream of the TrkB receptor and involves docking proteins insulin receptor substrate- 1 and Shc, which convey receptor activation to the downstream effectors. The functional consequences of $A \beta$ interference with signaling are robust, causing increased vulnerability of neurons, abrogating BDNF protection against DNA damage- and trophic deprivation-induced apoptosis. These new findings suggest that $\mathrm{A} \beta$ engenders a dysfunctional encoding state in neurons and may initiate and/or contribute to cognitive deficit at an early stage of AD before or along with neuronal degeneration.
\end{abstract}

Key words: $\beta$-amyloid; BDNF; CREB; MAPK; cortical neurons; PI3-K

\section{Introduction}

Alzheimer's disease (AD) is characterized by a progressive decline in cognitive functions. Hallmarks of the neuropathology include the accumulation of tangles, amyloid- $\beta$ (A $\beta)$-containing plaques, dystrophic neurites, and loss of synapses and neurons (Selkoe, 1999). It generally is believed that $\mathrm{A} \beta$ peptides contribute significantly to the pathogenesis of the disease, although the mechanisms are not understood clearly. Transgenic animals overexpressing $\mathrm{AD}$-associated mutant $\beta$-amyloid precursor protein (APP) mimic certain features of $\mathrm{AD}$, including the deposition of amyloid plaques and the development of cognitive deficits. However, although neurite degeneration is observed, neuron loss is not a consistent feature of the phenotype (Hsiao et al., 1996; Chapman et al., 1999; Hsia et al., 1999; Hardy and Selkoe, 2002). Furthermore, in certain animal models impaired performance in behavioral tests precedes abundant amyloid plaque deposition (Holcomb et al., 1998), suggesting that nondegenerative mechanisms may contribute to cognitive decline. Similarly, studies on postmortem brains are consistent with the view that

Received Dec. 12, 2003; revised April 9, 2004; accepted April 30, 2004. This work was supported by National Institutes of Health Grant R01-NS040953.

Correspondence should be addressed to Dr. Liqi Tong, Institute for Brain Aging and Dementia, University of California Irvine, Irvine, CA 92697-4540. E-mail: tongl@uci.edu.

DOI:10.1523/JNEUROSCI.5463-03.2004

Copyright $\odot 2004$ Society for Neuroscience $\quad$ 0270-6474/04/246799-11\$15.00/0 cognitive decline may precede the formation of plaques and neurodegenerative changes (Morris et al., 1996; Lue et al., 1999; Naslund et al., 2000; Snowdon et al., 2000). Thus, although it is well documented that $\mathrm{A} \beta$ peptides can cause neurodegeneration both in vivo and in vitro (Yankner, 1996), it seems that impairment of neuronal plasticity, including cognition, may precede both high levels of $A \beta$ accumulation and neuron loss in the brain.

$\mathrm{AD}$ is a progressive disease, and $\mathrm{A} \beta$ may be present in the brain at sublethal concentrations for extended periods before the overt manifestation of the disorder. Recently, we proposed that $A \beta$ at levels not compromising survival may affect neuronal function via critical signal transduction processes that mediate plastic changes, including those involved in learning and memory (Tong et al., 2001). In that study we observed that sublethal $\mathrm{A} \beta_{1-42}$ interferes with neuronal activity-dependent signaling, suppressing activation of the transcription factor cAMP response element-binding protein (CREB) that plays a critical role in learning and memory in different species (Bourtchuladze et al., 1994; Tully, 1997) and also has cell survival-promoting effects (Bonni et al., 1999).

One of the CREB target genes is brain-derived neurotrophic factor (BDNF), and the $A \beta_{1-42}$ treatment interfered with the CREB activation-induced transcription of the BDNF gene (Tong et al., 2001). BDNF has an important role, in its own right, in promoting neuronal survival, differentiation, and synaptic plas- 
ticity (Thoenen, 2000; Huang and Reichardt, 2001). In the present study we examined, therefore, the influence of sublethal concentrations of $A \beta_{1-42}$ on BDNF-induced signaling and neuroprotection in cultured rat cortical neurons, because BDNF might be not only a target but also one of the effectors of $A \beta_{1-42}$ action. The effects of BDNF are mediated by TrkB receptorinduced activation of key signaling pathways, including phospholipase C $\gamma$ (PLC $\gamma$ ), Ras-mitogen-activated protein kinase/extracellular signal-regulated protein kinase (MAPK/ERK), and phosphatidylinositol 3-kinase (PI3-K)/Akt pathways, leading to the activation of critical transcription factors such as CREB and Elk-1, which play crucial roles in neuronal physiology, including synaptic plasticity (Finkbeiner et al., 1997; Tully, 1997; Wasylyk et al., 1998; Huang and Reichardt, 2001).

Our current observations show that $\mathrm{A} \beta_{1-42}$ at sublethal levels suppresses BDNF-induced activation of selective signaling pathways by interfering at the level of docking proteins that mediate signaling to Ras-MAPK/ERK and PI3-K/Akt pathways. Taken together, our observations support a model in which sublethal $\mathrm{A} \beta$ interferes with signaling critical for neuronal function and plasticity and thus may contribute to the cognitive impairment that precedes the development of the $\mathrm{AD}$ characteristic neuropathology.

\section{Materials and Methods}

Cell culture. Cultures greatly enriched in cortical neurons from embryonic day 18 rat fetuses were prepared as described previously (Pike et al., 1993). Cells plated at $2.5 \times 10^{4} \mathrm{cells} / \mathrm{cm}^{2}$ were cultured in poly-L-lysinetreated multiwell plates and maintained in serum-free optimal DMEM supplemented with B27 components (Invitrogen, Carlsbad, CA). When cells were exposed to $A \beta$, the medium was switched to DMEM/B27 containing $\mathrm{A} \beta$. Cultures were maintained for $5 \mathrm{~d}$ before treatments. Neuronal survival was determined at $5 \mathrm{~d}$ in vitro (5 DIV) by trypan blue exclusion (Pike et al., 1993) or by use of the MTT assay (Ivins et al., 1999). Early apoptotic changes were assessed by using the Annexin V FLUOS staining kit (Roche Biochemicals, Indianapolis, IN).

Cells were treated with tetrodotoxin (TTX; $1 \mu \mathrm{M}$ ) and amino-5phosphonovaleric acid $(100 \mu \mathrm{M}) 2 \mathrm{hr}$ and $30 \mathrm{~min}$, respectively, before exposure to $\mathrm{A} \beta$ to reduce endogenous synaptic activity and to block glutamate release induced by BDNF ( $\mathrm{Li}$ et al., 1998; Numakawa et al., 2001 ) to reduce the basal level of activated signaling molecules (Chandler et al., 2001). Cells were treated with $A \beta$ for $2 \mathrm{hr}$ before the addition of BDNF (PeproTech, Rocky Hill, NJ). After 10-15 min of incubation with BDNF the cells were lysed and the preparations subjected to either electrophoresis or immunoprecipitation.

$\mathrm{A} \beta$ peptides $\left[\mathrm{A} \beta_{1-42}\right.$ and $\mathrm{A} \beta_{1-42}(\mathrm{R})$ with random amino acid sequence] were synthesized by solid-phase Fmoc [ $N$-(9-fluorenyl) methoxycarboxyl] amino acid chemistry, purified by reverse-phase HPLC, and characterized by electrospray mass spectrometry as previously described (Burdick et al., 1992; Pike et al., 1993). A stock solution of $\mathrm{A} \beta(1 \mathrm{mM})$ was prepared in distilled water and used after one freeze-thaw cycle. Preparations of $\mathrm{A} \beta_{1-42}$ oligomers were obtained from the same lot of $\mathrm{A} \beta_{1-42}$ peptides as the $\beta$-sheet containing $\mathrm{A} \beta_{1-42}$ preparations described above to facilitate the comparison of the two preparations. Solutions of $\mathrm{A} \beta_{1-42}$ oligomers were prepared as previously described (Oda et al., 1995; Lambert et al., 1998). In brief, $\mathrm{A} \beta_{1-42}(100 \mu \mathrm{M})$ in cold DMEM was vortexed and incubated at $4-8^{\circ} \mathrm{C}$ for $24 \mathrm{hr}$. Solutions were centrifuged at $14,000 \times g$ for $10 \mathrm{~min}$ to remove large aggregates, and the supernatant was used for all assays. In agreement with the published reports, microscopic examination of these preparations indicated that the supernatant contained no large aggregates.

Test for phosphatidyl serine externalization (annexin staining). Cells were grown on glass coverslips as above. At 5 DIV the cultures received $\mathrm{A} \beta_{1-42}$, and after $2 \mathrm{hr}$ the medium was removed and replaced with DMEM/B27. After an additional $2 \mathrm{hr}$ period annexin V-FLUOS and propidium iodide were added, and the cultures were viewed with confocal microscopy after $30 \mathrm{~min}$ of staining.
Western blots. Cultures of cortical neurons were lysed in SDS-sample buffer, and proteins, resolved by 10\% SDS-PAGE, were transferred to polyvinylidene difluoride membrane. Membranes were incubated in Tris-buffered saline (TBS) containing $0.1 \%$ Tween and 5\% nonfat milk for $60 \mathrm{~min}$ at room temperature to block nonspecific binding. Membranes were incubated additionally for $2 \mathrm{hr}$ at room temperature in the presence of the following antibodies as indicated: from Upstate Cell Signaling (Charlottesville, VA), phosphorylated CREB (P-CREB; detects CREB phosphorylated at Ser ${ }^{133} ; 1: 2000$ ), total CREB (T-CREB; 1:2000), Shc (the antibody recognizes all isoforms; $1: 1000)$, PLC $\gamma(1: 1000)$, total TrkB (T-TrkB; 1:1000); from Cell Signaling Technology (Beverly, MA), phosphorylated MAPK/ERK (P-MAPK; detects p44/42 MAPK phosphorylated at $\mathrm{Thr}^{202}$ and $\left.\mathrm{Tyr}^{204} ; 1: 2000\right)$, total MAPK (T-MAPK; 1:2000), phosphorylated Raf-1 (P-Raf-1; detects Raf-1 phosphorylated at Ser ${ }^{388}$; 1:1000), phosphorylated MEK1/2 (P-MEK1/2; detects MEK1/2 phosphorylated at Ser ${ }^{217 / 221} ; 1: 1000$ ), total MEK1/2 (T-MEK1/2; 1:1000), phosphorylated Elk-1 (P-Elk-1; detects Elk-1 phosphorylated at Ser $\left.{ }^{383} ; 1: 1000\right)$, total Elk-1 (T-Elk-1; 1:1000), phosphorylated Akt (PAkt; detects Akt phosphorylated at Ser $\left.{ }^{473} ; 1: 1000\right)$, total Akt (T-Akt; 1:1000), phosphorylated TrkB (P-TrkB; detects TrkB phosphorylated at $\left.\mathrm{Tyr}^{490} ; 1: 500\right)$. Membranes then were treated with HRP-conjugated secondary antibodies for $1 \mathrm{hr}$, followed by four washes with TBS containing $0.1 \%$ Tween. Immunolabeling was detected by enhanced chemiluminescence (Amersham Biosciences, Piscataway, NJ) according to the recommended conditions. Immunoreactivity was quantified by using densitometric analysis.

Immunoprecipitation. Cells were lysed in $500 \mu \mathrm{l}$ of immunoprecipitation buffer [ $1 \%$ Triton X-100 plus (in mM) $150 \mathrm{NaCl}, 50$ Tris, pH 8.0, 0.2 sodium orthovanadate, 0.2 phenylmethylsulfonyl fluoride, and $1 \mathrm{mg} / \mathrm{ml}$ each pepstatin, leupeptin, and antipain]. Lysates were centrifuged at $10,000 \times g$ for $30 \mathrm{~min}$, and protein concentration of the clarified lysates was determined by the Micro-BCA protein assay (Pierce, Rockford, IL). Proteins were immunoprecipitated with anti-insulin receptor substrate-1 (anti-IRS1)-, anti-Shc-, or agarose-linked anti-phosphotyrosine antibodies at $4^{\circ} \mathrm{C}$ overnight. After immunoprecipitation with anti-IRS-1 or anti-Shc antibodies the samples were rotated in the presence of protein G-Sepharose at $4^{\circ} \mathrm{C}$ for $2 \mathrm{hr}$. The immune complexes were pelleted by centrifugation at $10,000 \times g$ at $4^{\circ} \mathrm{C}$ for $1 \mathrm{~min}$. The supernatant was decanted, and the pellet was washed with $1 \mathrm{ml}$ of immunoprecipitation buffer. These steps were repeated three times; finally, the pellet was suspended in $60 \mu \mathrm{l}$ of SDSsample buffer (62.5 mM Tris, pH 6.8, 2\% SDS, 10\% glycerol, 5\% $\beta$-mercaptoethanol, $0.01 \%$ bromphenol blue). Proteins of the suspended immunoprecipitate $(30 \mu \mathrm{l})$ were separated on a 10\% SDS-PAGE gel. The immunoprecipitates were analyzed by Western blotting with anti-phosphotyrosine 4G10 (Upstate Cell Signaling) or PLC $\gamma$ (Upstate Cell Signaling) antibodies.

Immunocytochemistry. Cultures were fixed with $4 \%$ paraformaldehyde in $0.1 \mathrm{M}$ PBS, pH 7.4. After fixation the cultures were treated with a solution of $3 \%$ aqueous $\mathrm{H}_{2} \mathrm{O}_{2}$ for $3 \mathrm{~min}$ and then briefly rinsed with PBS. Cultures next were incubated with PBS containing 5\% bovine serum albumin (BSA) and $0.3 \%$ Triton $\mathrm{X}-100$ at room temperature for $1 \mathrm{hr}$, followed by additional incubation at $4^{\circ} \mathrm{C}$ in $\mathrm{PBS} / 5 \%$ BSA containing the rabbit polyclonal IgG against P-CREB (1:2000; Upstate Biotechnology, Lake Placid, NY). Cultures then were rinsed in buffer and incubated in biotinylated goat anti-rabbit IgG. After a buffer rinse the cultures were incubated in the presence of avidin-biotin complex (Vector Laboratories, Burlingame, CA) for $90 \mathrm{~min}$. They were rinsed in $0.1 \mathrm{~m} \mathrm{Tris-HCl,} \mathrm{pH}$ 7.6 , and treated with diaminobenzidine tetrahydrochloride $(0.05 \%$ in Tris- $\mathrm{HCl}$ ) and $0.01 \%$ hydrogen peroxide for 5-10 min. Reactions were stopped by rinsing the cultures with PBS.

Cortical neuron transfection and luciferase assay. Cortical neurons were transfected with the plasmid pCRE-Luc containing the cAMP response element (CRE) sequence (TGACGTCA)and pSRE-Luc containing the serum response element (SRE) sequence (CCATATTAGG) (Stratagene, La Jolla, CA) at 3 DIV with a procedure described by Myers et al. (1998). Briefly, cultures in six-well $35 \mathrm{~mm}$ dishes were transfected in the presence of Lipofectamine 2000 (Invitrogen) according to the manufacturer's instructions. Each well was transfected with $1 \mu \mathrm{g}$ of reporter plasmid and $0.1 \mu \mathrm{g}$ of pRL-CMV (Promega, Madison, WI), a CMV-luciferase control 
plasmid to normalize CRE and SRE activity. At $40 \mathrm{hr}$ after transfection the cultures received $50 \mathrm{ng} / \mathrm{ml}$ BDNF for $9 \mathrm{hr}$; then the plates were washed twice with cold PBS, and the cells were lysed with $200 \mu \mathrm{l}$ of lysis buffer (Promega). Cell extract $(20 \mu \mathrm{l})$ was used for a dual-luciferase reporter assay (Promega) according to the manufacturer's instructions.

Akt activity assay. Akt activity was determined with an Akt assay kit (Cell Signaling Technology) according to the manufacturer's instruction. The phosphorylation of a substrate of Akt (glycogen synthase kinase, GSK-3 $3 / \beta$ ) was measured by using immunoprecipitated Akt from cell lysates. Cell extracts $(200 \mu \mathrm{l})$ were incubated for $2 \mathrm{hr}$ with immobilized Akt 1G1 monoclonal antibody. After extensive washing the kinase reaction was performed in the presence of $200 \mu \mathrm{M}$ cold ATP and GSK$3 \alpha / \beta$ substrate. Phosphorylation of GSK- $3 \alpha / \beta$ was measured by Western blots, using phospho-GSK- $3 \alpha / \beta$ antibody (detects GSK- $3 \alpha$ containing phosphorylated $\operatorname{Ser}^{21}$ and GSK-3 $\beta$ containing $\operatorname{Ser}^{9}$ ).

Deprivation from trophic support. It was established that BDNF can protect neurons from cell death induced by serum deprivation (Hetman et al., 1999). Our cultures were maintained in the B27 serum-free medium that contains a great number of trophic ingredients providing comparable support for neuron survival as serum does but that prevents the proliferation of glial cells. We observed that deprivation from B27, like that from serum, compromised neuronal survival, thus permitting the testing of the effect of BDNF and $\mathrm{A} \beta_{1-42}$ on the survival of the deprived cells. In these studies the B27-containing medium was removed from the cultures at 4-6 DIV. Cells were washed twice with DMEM and then incubated in DMEM for $36 \mathrm{hr}$ in the absence or presence of $10 \mathrm{ng} / \mathrm{ml}$ $\mathrm{BDNF} \pm 5 \mu \mathrm{M} \mathrm{A} \beta_{1-42}$. Control cells were treated the same way but were incubated in B27-containing DMEM.

Camptothecin treatment. At 4-6 DIV the cortical neurons were treated with $5 \mu \mathrm{M}$ camptothecin for $24 \mathrm{hr}$, after a $1 \mathrm{hr}$ pretreatment with $10 \mathrm{ng} / \mathrm{ml}$ BDNF or vehicle in the presence or absence of $5 \mu \mathrm{MA} \beta_{1-42}$. Neuronal survival was determined by trypan blue exclusion.

\section{Results}

In a previous study, we observed that $\mathrm{A} \beta_{1-42}$ at sublethal concentrations inhibits neuronal activity-dependent phosphorylation of CREB and CREB-mediated gene expression, as exemplified by the suppression of the transcription of the CREB target BDNF gene (Tong et al., 2001). BDNF, a member of neurotrophin family, is an important factor for both the developing and mature neurons and has a pleiotropic influence on nerve cells, including effects on synaptic transmission and neuronal plasticity, in addition to regulating the survival, differentiation, and maintenance of specific neuronal populations (for review, see Thoenen, 2000; Huang and Reichardt, 2001). Mice deficient in either BDNF or its receptor TrkB exhibit impaired dendritic and axonal arborization, synaptic activity, and neuronal plasticity, including impairment in long-term potentiation (LTP) and learning and memory processes (Korte et al., 1995; Patterson et al., 1996; Causing et al., 1997; Martinez et al., 1998; Minichiello et al., 1999). In the current study we examined whether $\mathrm{A} \beta_{1-42}$, which at sublethal levels interferes with BDNF production, has an influence on BDNFinduced signal transduction, including CREB activation.

$\mathrm{A} \beta_{1-42}$ at the concentration range of $1-10 \mu \mathrm{M}$ did not compromise cell survival assessed by the technique of either trypan blue exclusion (Fig. 1) or MTT reduction (data not shown). Under our experimental conditions the toxic effect is manifested after exposure to $\geq 20 \mu \mathrm{M}$ of $\mathrm{A} \beta_{1-42}$ for $24 \mathrm{hr}$ (Ivins et al., 1999). Although neurons remained viable in the presence of $1-10 \mu \mathrm{M}$ $\mathrm{A} \beta_{1-42}$ during the experimental period that was studied, these sublethal concentrations may have triggered early apoptotic processes. Probing for such early changes, we demonstrated previously that activation of caspases, which play an important role in $\mathrm{A} \beta_{1-42}$-induced apoptosis, is not involved in the sublethal $\mathrm{A} \beta_{1-}$ 42 -induced suppression of the neuronal activity-evoked increase in phosphorylated CREB levels (Tong et al., 2001). As an early marker of apoptosis, here we examined the externalization of phosphatidyl serine (PS) to the outer leaflet of the plasma membrane, using annexin IV binding for detection (Martin et al., 1995). We estimated this early marker of apoptosis after a $4 \mathrm{hr}$ exposure to 1-10 $\mu \mathrm{M} \mathrm{A} \beta_{1-42}$, which is longer than the $2 \mathrm{hrA} \beta$ treatment that was the routine in most of the current experiments, and we observed no indication of PS externalization (data not shown).

BDNF-induced activation of CREB is suppressed by sublethal concentrations of $A \boldsymbol{\beta}_{1-42}$

We confirmed previous observations [Iida et al. (2001) and references therein] and found that BDNF elicited a marked increase in cultured cortical neurons in the level of CREB phosphorylated at the critical Ser ${ }^{133}$ (P-CREB) (Fig. 2). Pretreatment with A $\beta_{1-42}$ in the subtoxic range for $2 \mathrm{hr}$ resulted in a concentrationdependent decrease in the effect of BDNF on P-CREB levels without affecting the total amount of CREB (T-CREB) (Fig. 2A,B). The effect was specific, because $A \beta_{1-42}$ with random sequence of amino acid residues $[\mathrm{A} \beta(\mathrm{R})]$ failed to influence BDNF-induced activation of CREB (Fig. 2C). Furthermore, $2 \mathrm{hr}$ exposure to $\mathrm{A} \beta_{1-42}$ alone had no significant effect on basal P-CREB levels (Fig. 2E). We also examined the effect of $\mathrm{A} \beta_{1-42}$ treatment on BDNF-induced CREB activation via immunocytochemistry (Fig. $2 D)$. BDNF elicited a pronounced increase in P-CREB immunoreactivity in almost all neurons, and this effect was attenuated markedly by exposure to $5 \mu \mathrm{M} \mathrm{A} \beta_{1-42}$.

To examine the consequences of the suppression of $A \beta$ at sublethal concentrations on BDNF-mediated CREB activation, we analyzed the effect of the peptide on transcriptional activity of a promoter construct containing CRE sequences. Effects were monitored by a transient transcription activity assay with luciferase as a reporter gene. BDNF increased the CRE transcription activity, and pretreatment with $\mathrm{A} \beta_{1-42}$ reduced by $\sim 50 \%$ the induction by BDNF (Fig. 2 F).

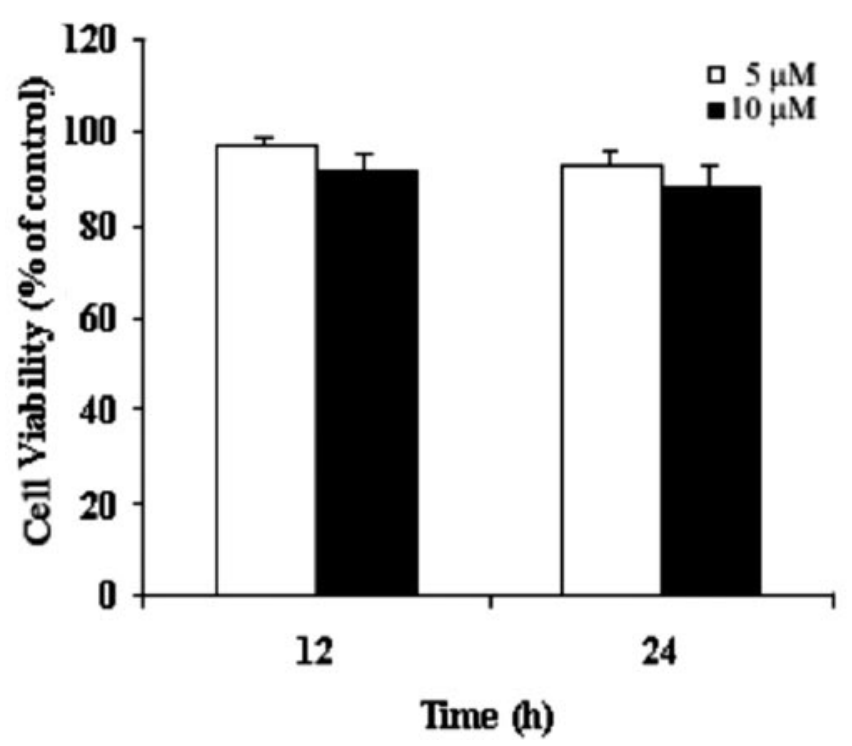

Figure 1. Viability of cortical neurons after $A \beta_{1-42}$ treatment. Cortical neuronal cultures at 5 DIV were treated with $A \beta_{1-42}$ at the indicated concentrations and length of time. Viability was determined by the trypan blue exclusion assay. Data shown are the mean $\pm \mathrm{SE}(n=4)$. In three separate experiments cell viability was measured with the MTT assay, which showed no significant reduction after exposure to $10 \mu \mathrm{MA} \beta_{1-42}$ for $24 \mathrm{hr}$. 
Effect of sublethal concentrations of A $\boldsymbol{\beta}_{1-42}$ on MAPK activation

Various pathways can mediate CREB activation. In our previous study CREB phosphorylation was evoked by the stimulation of neurons with NMDA $(10 \mu \mathrm{M})$ or elevated $\mathrm{K}^{+}(30 \mathrm{~mm})$, and under these conditions pathways other than the Ras/ MAPK pathway are involved primarily in CREB activation (Iida et al., 2001). In the present work the neurons were exposed to BDNF, when the activation of the RasMAPK pathway plays a dominant role in CREB phosphorylation (Iida et al., 2001).

MAPKs are highly expressed in neurons, and it has been shown that the ERK isoforms, in particular, are important regulators of synaptic plasticity (Sweatt, 2001) in addition to their more general critical role in cell proliferation and differentiation (Marshall, 1994). Because BDNF-induced CREB activation was compromised by the $\mathrm{A} \beta_{1-42}$ treatment and the MAPK/ERK pathway seems to play a dominant role in BDNF signaling to CREB, we examined the influence of sublethal level of $\mathrm{A} \beta_{1-42}$ on the BDNF-induced activation of MAPK (Fig. $3 A, B$ ).

Under our experimental conditions, which included transmission blockade via TTX and the inhibition of NMDA receptors, the basal level of dual-phosphorylated MAPK/ERK was very low (Chandler et al., 2001). Exposure to BDNF (50 ng/ml) for $10 \mathrm{~min}$ caused a robust increase in the amount of both the phosphorylated p42 and p44 isoforms of MAPK. Pretreatment with sublethal concentrations of $\mathrm{A} \beta_{1-42}$ for $2 \mathrm{hr}$ had no significant effect on the basal level of phosphorylated MAPK (data not shown) but resulted in a decrease in the BDNF-elicited activation of both MAPK isoforms (Fig. 3A,B).

\section{Diffusible $\mathrm{A} \boldsymbol{\beta}_{1-42}$ oligomers decrease with high-potency BDNF-induced signal transduction}

There is evidence that diffusible $\mathrm{A} \beta$ oligomers are more potent than the conventional fibrillar $\mathrm{A} \beta$ preparations in compromising neuronal function and survival (Lambert et al., 1998; Walsh et al., 2002). We also observed previously that, in comparison with our conventional $\mathrm{A} \beta_{1-42}$ preparation, the diffusible oligomeric form of $\mathrm{A} \beta_{1-42}$ (see Materials and Methods) is more potent both in inducing neurotoxicity and at sublethal concentrations interfering with high $\mathrm{K}^{+}$-induced CREB phosphorylation (Tong et al., 2001). Here we examined the effect of this $A \beta_{1-42}$ oligomer preparation on the BDNF-induced activation of the CREB. We confirmed our earlier observation that the $\mathrm{A} \beta_{1-42}$ oligomers are neurotoxic at concentrations $\geq 1 \mu \mathrm{M}$ (data not shown). At the sublethal concentration of $200 \mathrm{~nm}$ the $\mathrm{A} \beta_{1-42}$ oligomers suppressed the BDNF-induced increase in the amount of the phosphorylated CREB (Fig. 4A,B).

We also examined the effect of a sublethal concentration of the Student's $t$ test).
B

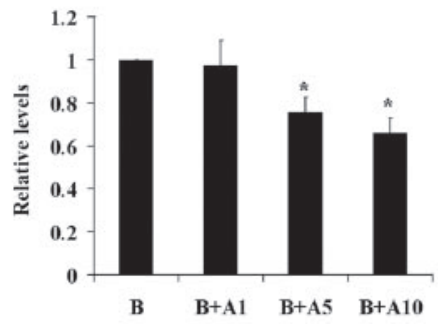

D

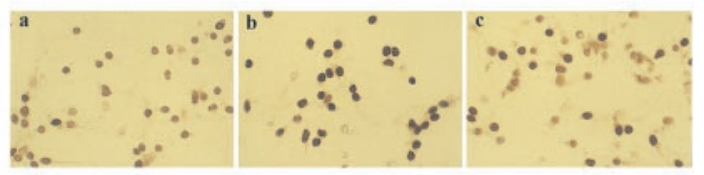

F

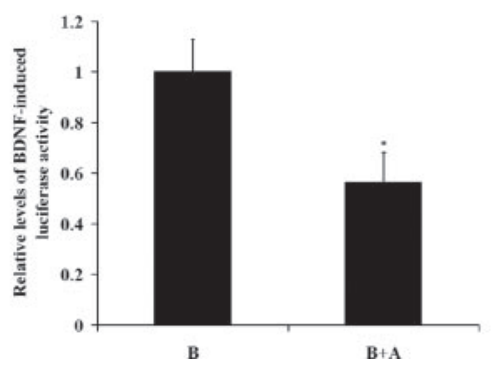

$\mathbf{B}+\mathbf{A}$

Figure 2. Pretreatment with sublethal concentrations of $A \beta_{1-42}(5$ or $10 \mu \mathrm{m})$ for $2 \mathrm{hr}$ decreased the elevation of phosphorytotal CREB (T-CREB). $A \beta_{1-42}$ treatment resulted in a concentration-dependent decrease in the level of $P$-CREB but, considering all experiments $(n=3)$, had no significant effect on T-CREB levels. B, Quantification of the effect of pretreatment with 1, 5, or $10 \mu \mathrm{N}$ $\beta_{1-42}$ was significant $\left({ }^{*} p<0.05\right.$, unpaired Student's $t$ test). C, Pretreatment with $10 \mu \mathrm{M} \mathrm{A} \beta_{1-42}$ with random amino acid P-CREB. P-CREB immunoreactivity increased in BDNF-stimulated cultures $(b)$ compared with unstimulated control ( $a$ ). BDNFced increase in P-CREB immunoreactivity was suppressed by $A \beta_{1-42}(5 \mu \mathrm{m})$ treatment $(c)$. E, Exposure of the cultures to

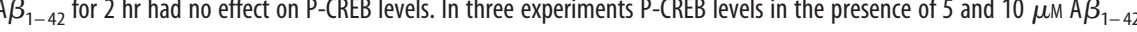
spectively, were $104 \pm 2$ and $105 \pm 6 \%$ of basal. F, Analysis of CRE-mediated transcriptional activity. Cortical neurons at 3 DIV 作 $(n=3)$ expressed in terms of BDNF-induced transcriptional activity. The effect of $A \beta_{1-42}$ was significant $\left({ }^{*} p<0.05\right.$, unpaired

$\mathrm{A} \beta_{1-42}$ oligomer preparation on the BDNF-induced activation of the MAPK. Pretreatment with $200 \mathrm{~nm} \mathrm{~A} \beta_{1-42}$ oligomers decreased significantly the BDNF-induced increase in the amount of the phosphorylated p42 and p44 isoforms of MAPK (Fig. $4 C, D)$

Effect of sublethal concentrations of $A \beta_{1-42}$ on the activation of Elk-1, a transcription factor downstream of MAPK/ERK ERK activated as a result of BDNF-induced signal transduction can translocate to the nucleus and phosphorylate transcription factors, including Elk-1. Elk-1 is a member of the ternary complex factor (TCF) family (Wasylyk et al., 1998) and functions as a nuclear transcriptional activator via its association with serum response factor (SRF) in a ternary complex on the SRE sequence that is present in the promoter of many genes, including immediate early genes (Wasylyk et al., 1998). Exposing cortical neurons 
$\mathbf{A}$

B

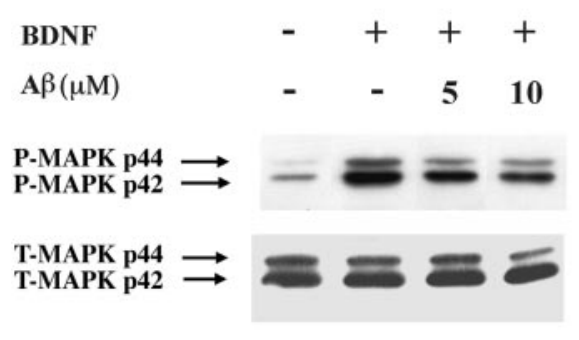

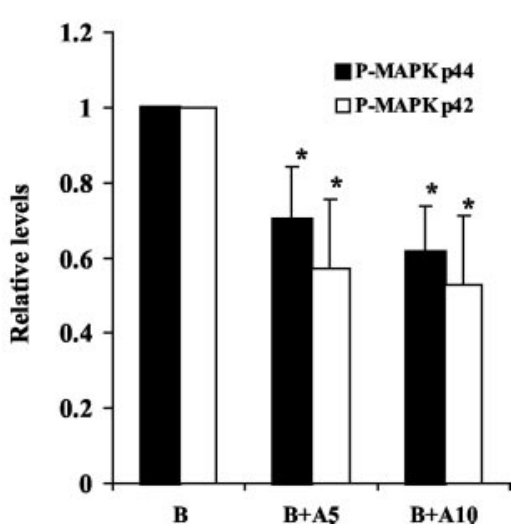

Figure 3. Pretreatment with sublethal $A \beta_{1-42}(5$ or $10 \mu \mathrm{m})$ decreased the BDNF-induced increase in the level of phosphorylated p42- and p44-MAPK/ERK elicited by stimulation with BDNF $(50 \mathrm{ng} / \mathrm{ml}, 10 \mathrm{~min})$. $A$, Western blot analysis showed that $A \beta_{1-42}$ exposure resulted in a concentration-dependent decrease in the level of phosphorylated $p 42$ - and $p 44-M A P K$ ( $p 42$ - and p44-P-MAPK). B, Quantification of the effects of pretreatment with 5 or $10 \mu \mathrm{M} \mathrm{A} \beta_{1-42}$. Estimates are the mean \pm SEM $(n=3)$ expressed in terms of $p 42$ - and p44-P-MAPK levels obtained in the BDNF-exposed cultures. Effects of 5 and $10 \mu \mathrm{M} \mathrm{A} \beta_{1-42}(A 5$, A10) were significant $\left({ }^{*} p<0.05\right.$, unpaired Student's $t$ test).
A

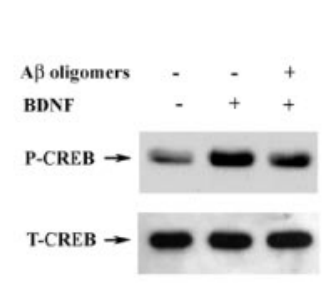

C

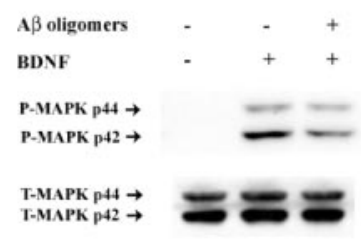

B

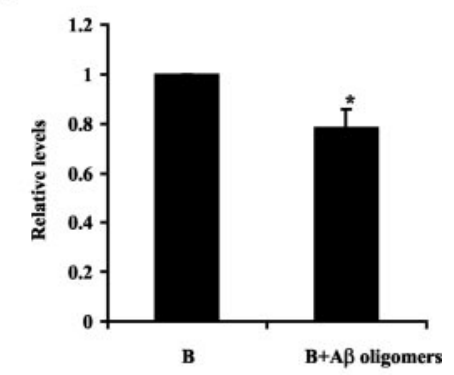

D

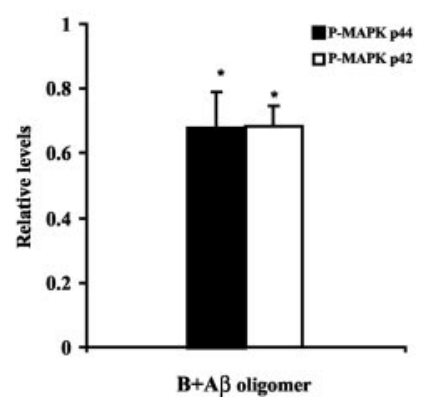

Figure 4. A preparation comprising diffusible $A \beta_{1-42}$ oligomers interferes with high potency with $B D N F-i n d u c e d$ signaling. $A$, Western blots showing that pretreatment $(1 \mathrm{hr}$ ) with an $A \beta_{1-42}$ oligomer preparation at the sublethal concentration of $200 \mathrm{~nm}$ compromised the increase in P-CREB levels induced by BDNF ( $50 \mathrm{ng} / \mathrm{ml}, 10 \mathrm{~min})$. $B$, Quantification of the effect of $200 \mathrm{~nm} \mathrm{~A} \beta_{1-42}$ oligomers. Estimates are the mean \pm SEM $(n=3)$ expressed in terms of P-CREB levels obtained in BDNF-treated cultures. The effect of $200 \mathrm{nM} \mathrm{A} \beta_{1-42}$ oligomers was significant $\left({ }^{*} p<0.05\right.$, unpaired Student's $t$ test). C, Western blot analysis of P-MAPK. Pretreatment with $200 \mathrm{~nm} \mathrm{~A} \beta_{1-42}$ oligomers for $1 \mathrm{hr}$ attenuated the increase in P-MAPK levels by exposure to 50 $\mathrm{ng} / \mathrm{ml}$ BDNF for $10 \mathrm{~min}$. D, Quantification of the effect of pretreatment with $200 \mathrm{~nm} \mathrm{~A} \beta_{1-42}$ oligomers for $1 \mathrm{hr}$. Estimates are expressed in terms of P-MAPK levels obtained in the BDNFtreated cultures; they are the mean \pm SEM from three independent experiments. The effect of $A \beta_{1-42}$ oligomers was significant $\left({ }^{*} p<0.05\right.$, unpaired Student's $t$ test).

to BDNF increased the level of phosphorylated Elk-1 (P-Elk-1) (Fig. 5A). Pretreatment with 5 or $10 \mu \mathrm{M} \mathrm{A} \beta_{1-42}$ caused a marked decrease in the amount of P-Elk-1 in the BDNF-treated cultures (Fig. 5A,B).
To evaluate the consequences of the action of sublethal concentrations of $A \beta$ on Elk-1 mediated gene expression, we analyzed the effect of the peptide on transcriptional activity of promoter constructs containing SRE sequences. The effects were monitored with a transient transcription activity assay with luciferase as a reporter gene. BDNF increased the SRE transcription activity, and pretreatment with $\mathrm{A} \beta_{1-42}$ reduced the induction by BDNF by $\sim 50 \%$ (Fig. $5 C$ ).

Sublethal concentrations of $A \boldsymbol{\beta}_{1-42}$ suppressed BDNF-induced signal transduction upstream of MAPK

Next we examined whether the interference by $\mathrm{A} \beta_{1-42}$ with the BDNF-induced activation of MAPK/ERK is attributable to effects at steps in the signaling cascade upstream of MAPK. MAPK is activated by MEK (MAPK kinase or MAPKK) that is, in turn, phosphorylated by activated c-Raf (Marshall, 1994). The levels of phosphorylated Raf-1 (P-Raf-1) and phosphorylated MEK (P-MEK1/2) in cortical neurons were examined by Western blotting with antibodies specific to P-Raf- 1 and phosphorylated MEK1/2, respectively. BDNF exposure elicited an increase in the levels of both the P-Raf (Fig. 6A,B) and P-MEK1/2 (Fig. 6C,D). Pretreatment with $5 \mu \mathrm{M} \mathrm{A} \beta_{1-42}$ for $2 \mathrm{hr}$ resulted in a significant suppression of the BDNF-induced increase in activated Raf- 1 and MEK $1 / 2$ content without influencing the total amount of Raf-1 (T-Raf-1) and MEK1/2 (T-MEK1/2).

Sublethal levels of $\mathrm{A} \boldsymbol{\beta}_{1-42}$ and the BDNF-induced activation of the PI3-K pathway

BDNF activates, in addition to the Ras-MAPK pathway, signaling via PI3-K (Huang and Reichardt, 2001). PI3-K generates 3'phosphorylated phosphoinositides that act via multiple mechanisms to regulate the downstream effectors of PI3-K, including protein kinase B or Akt (Datta et al., 1999). The increase in 3'phosphorylated phosphoinositides results in the translocation of Akt from cytoplasm to the inner surface of plasma membrane. A conformational change after lipid binding permits the activation of Akt via phosphorylation of $\mathrm{Thr}^{308}$ and $\mathrm{Ser}^{473}$ by a protein kinase complex containing $3^{\prime}$-phospholipid-dependent protein kinases (PDK). Activated Akt is a major factor mediating the cell survivalpromoting effect of neurotrophins (Bonni et al., 1999), including the effect of BDNF in preventing cell death induced by serum deprivation (Hetman et al., 1999). To investigate the effect of $\mathrm{A} \beta_{1-42}$ on the activation of the PI3-K/Akt pathway, we examined the level of Akt phosphorylated at the critical Ser ${ }^{473}$ residue, using a specific antibody in Western blotting. Exposure of cortical neurons to BDNF resulted in a marked increase in the level of activated Akt (Fig. 7). Pretreatment with $\mathrm{A} \beta_{1-42}$ suppressed this response in a concentration-dependent manner (Fig. 7A,B). We also examined the effect of $A \beta_{1-42}$ on Akt activity, which was determined by estimating the phosphorylation of an Akt substrate, GSK-3 $\alpha / \beta$, using immunoprecipitates obtained from cell lysates treated with Aktspecific antibodies. BDNF induced a massive $>10$-fold increase in Akt kinase activity (Fig. $7 C$ ). $\mathrm{A} \beta_{1-42}$ alone failed to affect the basal level of activated CREB (Fig. 2E) or MAPK/ERK (data not shown) but elicited a slight increase $(50 \pm 13 \%$ above basal level) in Akt activity that was similar to the effect of the peptide on PC12 and 
SH-SY5Y neuroblastoma cells (Martin et al., 2001; Wei et al., 2002). The effect of $A \beta_{1-42}$ pretreatment on the robust increase in the BDNF-evoked Akt activity was, however, a suppression by $>50 \%$ (Fig. 7C,D).

\section{Effect of $A \boldsymbol{\beta}_{1-42}$ on BDNF-induced} activation of PLC $\gamma$

In addition to the Ras-MAPK and PI3-K/ Akt signaling cascades, BDNF also activates another major signal transduction pathway involving PLC $\gamma$ (Huang and Reichardt, 2001). To assess the influence of sublethal levels of $A \beta_{1-42}$ on the activation of this pathway by BDNF, we determined the amount of Tyr-phosphorylated PLC $\gamma$ by Western blot analysis, probing with an anti-PLC $\gamma$-specific antibody the immunoprecipitate obtained from cell lysates by an anti-phosphotyrosine antibody (Fig. $8 A$ ). BDNF caused a pronounced increase in Tyr-phosphorylated PLC $\gamma$, which was not influenced significantly by $\mathrm{A} \beta_{1-42}$ pretreatment.

\section{$\mathrm{A} \boldsymbol{\beta}_{1-42}$ does not interfere with the BDNF-induced phosphorylation of TrkB receptors}

In contrast to Ras and PI3-K, PLC $\gamma$ binds to and is phosphorylated directly by the activated TrkB receptor (Huang and Reichardt, 2001). Because $\mathrm{A} \beta_{1-42}$ interfered with BDNF activation of the Ras-MAPK and the PI3-K/Akt pathways, which are activated indirectly by TrkB but did not influence the phosphorylation of PLC $\gamma$ that is activated directly by the receptor, we hypothesized that $\mathrm{A} \beta_{1-42}$ might not have compromised the BDNF-induced activation of the TrkB receptor. Autophosphorylation of TrkB was assessed by Western blotting, using an antibody specific to the phosphorylated $\mathrm{Tyr}^{490}$ residue. BDNF resulted in pronounced autophosphorylation of the TrkB receptor, which was not compromised by pretreatment with $\mathrm{A} \beta_{1-42}$ (Fig. $8 B$ ). Thus, the peptide interferes with BDNF-induced signaling at steps downstream of the BDNF receptor.

\section{$\mathrm{A} \boldsymbol{\beta}_{1-42}$ at sublethal concentrations interferes with the phosphorylation of docking proteins that mediate the effects of BDNF on intracellular signaling pathways}

Our findings showed, therefore, that treatment with sublethal concentrations of $\mathrm{A} \beta_{1-42}$ interferes selectively with BDNF signaling via the MAPK/ERK and PI3-K pathways, but the initial step, the activation of the receptor, is unaffected, whereas the phosphorylation of intermediate members of the relevant PK cascades, such as Raf, MEK, and Akt, is compromised. The activation of the signaling pathways that were affected by $\mathrm{A} \beta_{1-42}$, the PI3-K and Ras-MAPK/ERK pathways, requires interactions of the activated BDNF receptor with docking proteins that, after phosphorylation, mediate the stimulation of the TrkB receptor to the protein kinase cascades. In contrast, the activated TrkB receptor directly binds and phosphorylates PLC $\gamma$, and $A \beta_{1-42}$ did not affect this process (see above). It is possible, therefore, that $\mathrm{A} \beta_{1-42}$ interferes with signal transduction at the level of the docking proteins. We examined the state of Tyr phosphorylation of IRS-1 that activates both PI3-K and, via Grb2/SOS, the RasMAPK/ERK pathway as well the phosphorylation of Shc that mediates signaling via Grb2/SOS to Ras. Figure 9 shows that
B
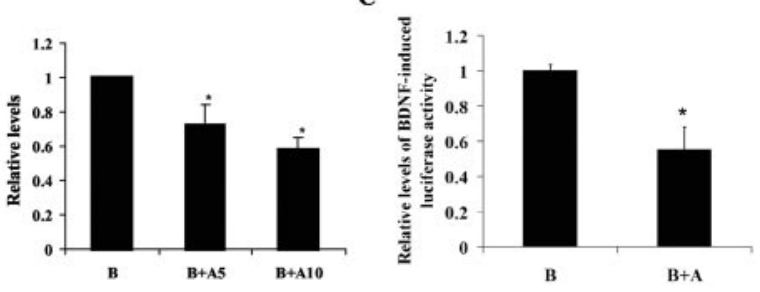

Figure 5. Pretreatment with $A \beta_{1-42}$ at sublethal concentrations decreased the level of BDNF-activated transcription factor Elk-1 (P-Elk-1) and the transcriptional activity of a serum response element-containing (SRE) construct. $A$, The phosphorylation of unpaired Student's $t$ test). C, Analysis of SRE-mediated transcriptional activity. Cortical neurons at 3 DIV were transfected with plasmid pSRE-Luc containing SRE sequences and a luciferase reporter gene (see Materials and Methods). Cells mates are the mean \pm SEM $(n=3)$ expressed in terms of BDNF-induced transcriptional activity. The effect of $A \beta_{1-42}$ was significant $\left({ }^{*} p<0.05\right.$, unpaired Student's $t$ test).

$\mathbf{A}$

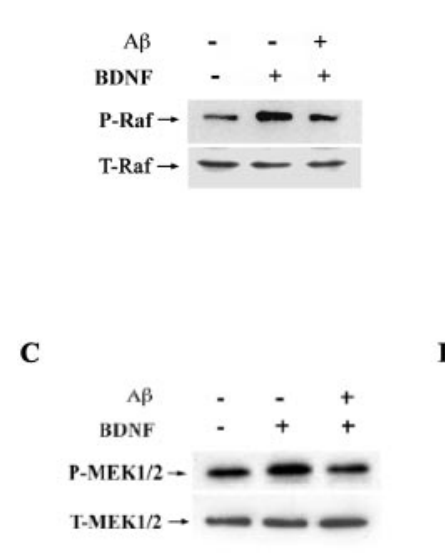

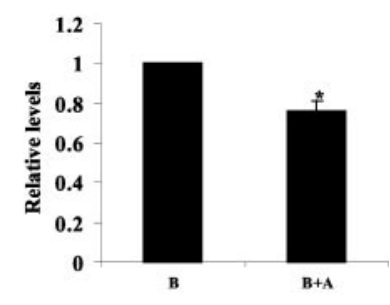

D

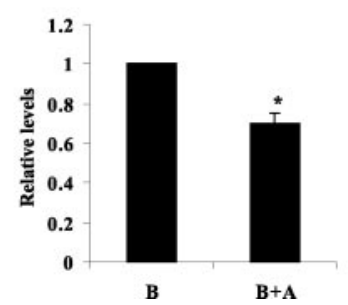

Figure 6. Sublethal $A \beta_{1-42}$ treatment decreased the phosphorylated levels of protein kinases in the MAPK cascade (P-Raf and P-MEK). $A$, The phosphorylation of Raf was examined by the use of an antibody against phosphorylated Raf- 1 (P-Raf). Pretreatment with $5 \mu \mathrm{m} \mathrm{A} \beta_{1-42}$ for $2 \mathrm{hr}$ attenuated the BDNF-induced increase in P-Raf. $B$, Quantification of the effects of pretreatment with $5 \mu \mathrm{MA} \beta_{1-42}$. Estimates are the mean $\pm \operatorname{SEM}(n=3)$ expressed in terms of P-Raf levels induced by BDNF (represented by $B$ ). Effects of $5 \mu \mathrm{mA} \beta_{1-42}(B+A)$ were significant $\left({ }^{*} p<0.05\right.$, unpaired Student's $t$ test). $C$, Pretreatment with $5 \mu \mathrm{MA} \beta_{1-42}$ decreased the BDNF-induced elevation in the level of phosphorylated MEK1/2 (P-MEK1/2). D, Quantification of the effects of pretreatment with $5 \mu \mathrm{M} \mathrm{A} \beta_{1-42}$ on BDNF-induced MEK1/2 phosphorylation. Estimates are the mean \pm SEM $(n=3)$ expressed in terms of P-MEK $1 / 2$ levels induced by BDNF. Effects of $5 \mu \mathrm{m} \mathrm{A} \beta_{1-42}(B+A)$ were significant $\left({ }^{*} p<0.05\right.$, unpaired Student's $t$ test).

$\mathrm{A} \beta_{1-42}$ caused an $\sim 50 \%$ reduction in the level of the activated IRS- 1 and suppressed the tyrosine phosphorylation of the different Shc isoforms.

$A \beta_{1-42}$ at sublethal concentrations interferes with the protection by BDNF against neuronal apoptosis induced by either DNA damage or deprivation from trophic support The observations described so far showed that $\mathrm{A} \beta_{1-42}$ at sublethal concentrations interferes selectively with some BDNF-induced 
$\mathbf{A}$

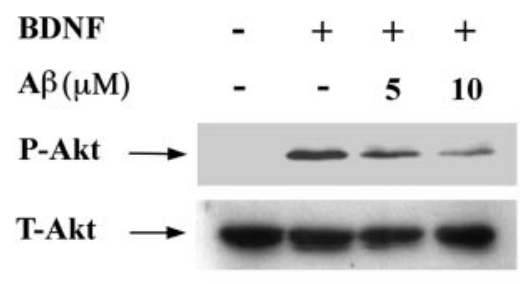

C

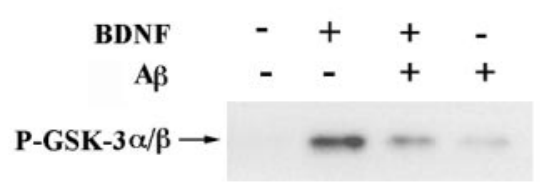

B

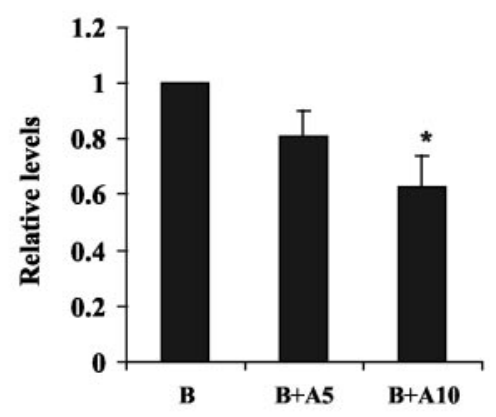

D

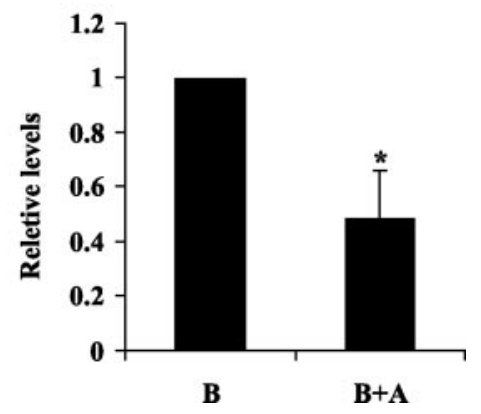

Figure 7. $A \beta_{1-42}$ treatment decreased BDNF-induced Akt activation. A, Phosphorylated Akt (P-Akt) levels were determined with an antibody specific to P-Akt. Exposure to BDNF $(50 \mathrm{ng} / \mathrm{ml})$ for 10 min increased the amount of P-Akt. Pretreatment with 5 or $10 \mu \mathrm{M} A \beta_{1-42}$ suppressed the effect of BDNF. $A \beta_{1-42}$ had no effect on total Akt (T-Akt) levels. $B$, Quantification of the effect of pretreatment with 5 or $10 \mu \mathrm{MA} \beta_{1-42}$. Estimates are the mean \pm SEM $(n=3)$ expressed in terms of P-Akt levels obtained in the BDNF-exposed cultures. The effect of $A \beta_{1-42}$ at $10 \mu \mathrm{m}$ was significant ( ${ }^{*} p<0.05$, unpaired Student's $t$ test). C, Pretreatment with $10 \mu \mathrm{MA} \beta_{1-42}$ decreased BDNF-induced Akt activity, measured by the phosphorylation of glycogen synthase kinase- $3 \alpha / \beta$ $(G S K-3 \alpha / \beta)$, a substrate of Akt, using immunoprecipitated Akt from cell lysates as described in Materials and Methods. $D$, Quantification of the effects of pretreatment with $10 \mu \mathrm{mA} \beta_{1-42}$. Estimates are the mean $\pm \operatorname{SEM}(n=3)$ expressed in terms of phosphorylated GSK-3 $\alpha / \beta$ levels obtained in the BDNF-exposed cultures. The effect of $A \beta_{1-42}$ was significant $\left({ }^{*} p<0.05\right.$, unpaired Student's $t$ test).

$\mathbf{A}$

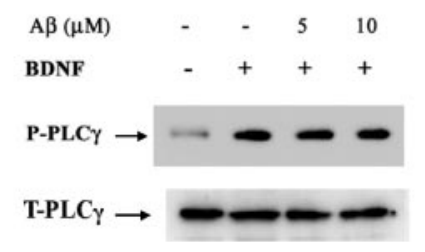

B

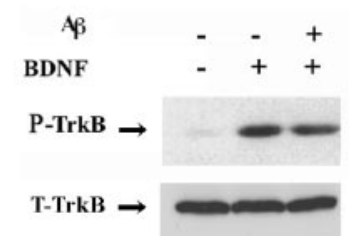

Figure 8. $A \beta_{1-42}$ at sublethal concentrations does not interfere with the activation of TrkB

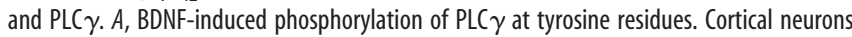
were stimulated with $50 \mathrm{ng} / \mathrm{ml}$ BDNF for $10 \mathrm{~min}$. Cell lysates were immunoprecipitated by agarose-linked anti-phosphotyrosine antibodies, and proteins of the washed immunoprecipitates were resolved by SDS-PAGE and subjected to Western blot analysis with a specific antiPLC $\gamma$ antibody (P-PLC $\gamma$ ). BDNF-induced PLC $\gamma$ phosphorylation was not influenced significantly by $A \beta_{1-42}$ pretreatment; in terms of phosphorylated PLC $\gamma$ levels obtained in the BDNFexposed cultures, the estimate in the $A \beta_{1-42}$-treated cultures was $92 \pm 7.1 \%(5 \mu \mathrm{M})$ and $97 \pm 7.2 \%(10 \mu \mathrm{M})(n=3)$. B, Phosphorylation of TrkB was examined via Western blotting with an antibody against TrkB phosphorylated at $\operatorname{Tyr}^{490}$ (P-TrkB). Pretreatment with $10 \mu \mathrm{M}$ $A \beta_{1-42}$ had no significant influence on the BDNF-induced P-TrkB content; in terms of $P$-TrkB levels obtained in the BDNF-exposed culture, the estimate in the $A \beta_{1-42}$-pretreated cells was $94 \pm 4.1 \%(n=3)$.

signal transduction pathways in cortical neurons. Next we wanted to explore the effect of the $\mathrm{A} \beta_{1-42}$ treatment on one of the important functions of BDNF, namely the selective protection of neurons against certain types of insults. BDNF can protect cortical neurons from apoptosis induced by camptothecin, an inhib-

itor of DNA topoisomerase- 1 that causes DNA damage (Morris and Geller, 1996). It has been reported that the protective effect of BDNF involves the activation of the MAPK signaling pathway (Hetman et al., 1999). Because sublethal concentrations of $\mathrm{A} \beta_{1-42}$ suppressed BDNF-induced activation of this pathway, we hypothesized that the peptide might interfere with BDNF protection from camptothecin-evoked cell death. Cortical neurons were exposed to 5 $\mu \mathrm{M}$ camptothecin for $24 \mathrm{hr}$ after $1 \mathrm{hr}$ of pretreatment with BDNF or vehicle in the presence or absence of $5 \mu \mathrm{M} \mathrm{A} \beta_{1-42}$. Figure $10 \mathrm{~A}$ shows that camptothecin treatment caused massive cell loss that was reduced markedly by BDNF treatment and that 5 $\mu \mathrm{M} \mathrm{A} \beta_{1-42}$ abolished BDNF protection.

Hetman et al. (1999) also have observed that the BDNF neuroprotection against serum deprivation-induced apoptosis is mediated by the PI3-K/Akt pathway. We tested the protective effect of BDNF on cultures that were deprived from the trophic support provided by the B27 medium. Removal of this medium resulted in significant cell loss by $36 \mathrm{hr}$, which was prevented completely by BDNF treatment (Fig. 10). The positive effect of BDNF again was compromised severely by sublethal concentrations of $\mathrm{A} \beta_{1-42}$.

\section{Discussion}

We currently are testing the hypothesis that $\mathrm{A} \beta$ peptides interfere with neuronal functions that play important roles in cognition before massive $\mathrm{A} \beta$ deposition and overt neurodegenerative changes occur in the brain in $\mathrm{AD}$. To this end we have chosen to examine the effect of $A \beta$ on signal transduction mechanisms that play critical roles in neuronal plasticity. In an earlier study (Tong et al., 2001) we showed that $\mathrm{A} \beta_{1-42}$ at concentrations at which the viability and the morphology of the cortical neurons are not affected suppressed high $\mathrm{K}^{+}$- or NMDA-induced activation of the transcription factor CREB that is known to play a major role in neuronal plastic changes underlying certain cognitive functions (Tully, 1997; Abel and Kandel, 1998). The effect of sublethal $\mathrm{A} \beta_{1-42}$ on Glu receptor activation-induced elevation of P-CREB levels recently has been confirmed by Vitolo et al. (2002), who also found that the suppression involves protein kinase A inactivation and can be overcome by the activation of the enzyme, which is consistent with the fact that CREB can be phosphorylated by many protein kinases.

The suppression by $A \beta_{1-42}$ of the neuronal activity-induced $\mathrm{P}$-CREB levels also results in a decrease in the transcription of CREB target genes, as demonstrated by the reduction of BDNF expression (Tong et al., 2001), and BDNF has been shown to participate in certain forms of LTP and learning and memory (Thoenen, 2000; Huang and Reichardt, 2001). In the present study we examined the effect of sublethal levels of $A \beta_{1-42}$ on signal transduction evoked by BDNF, which under our experimental conditions involves the dominant activation of pathways different from those mediating the effects of membrane depolarization and NMDA receptor activation used in our previous study for neuronal stimula- 
tion (Tong et al., 2001). A $\beta_{1-42}$ treatment resulted in a suppression of the BDNFinduced activation of critical transcription factors, such as CREB and Elk-1, and of CRE- as well as SRE-mediated transcriptional activity, suggesting that $\mathrm{A} \beta$ at sublethal levels initiates a vicious cycle in which the effect of the decrease in neuronal stimulation-induced trophic factor production is amplified by the suppression of the trophic factor-elicited signaling and may lead to severe interference with neuronal activity-dependent gene expression.

Under our experimental conditions $\mathrm{A} \beta_{1-42}$ did not compromise cell survival; nevertheless, the concentrations (5-10 $\mu \mathrm{M})$ were relatively high. However, in the $\mathrm{AD}$ brain and in culture after $\mathrm{A} \beta$ exposure the peptide accumulates on/in the neuronal plasma membrane, where the concentration is unknown, and in the $\mathrm{AD}$ brain $\mathrm{A} \beta$ realizes even higher concentrations in senile plaques and diffuse deposits. There also are marked differences in sensitivity in vitro, depending on the preparation and the function studied. For example, similar to us, Vitolo et al. (2002) observed that a sublethal concentration of $5 \mu \mathrm{M} \mathrm{A} \beta_{1-42}$ is required to suppress glutamate-stimulated P-CREB levels in dissociated hippocampal cultures, whereas $200 \mathrm{~nm} \mathrm{~A} \beta_{1-42}$ severely impairs LTP in hippocampal slices. Finally, we observed that an oligomer $\mathrm{A} \beta_{1-42}$ preparation interfered with neuronal activity- or BDNF-induced CREB activation at lower concentrations $(100-200$ $\mathrm{nM})$ compared with the routine $\mathrm{A} \beta$ preparation used in our studies (Tong et al., 2001; this work).

The dominant pathways leading to CREB activation after brief stimulation of neurons with BDNF or high $\mathrm{K}^{+} / \mathrm{NMDA}$ are different and involve primarily the activation of the Ras-MAPK pathway (Iida et al., 2001) or $\mathrm{Ca}^{2+}$ and calmodulin (CaM)mediated reactions (Deisseroth et al., 1998; Shieh et al., 1998; Tao et al., 1998). CREB phosphorylation at $\operatorname{Ser}^{133}$ also may involve activated Akt (Du and Montminy, 1998), and we observed that $\mathrm{A} \beta_{1-42}$ treatment also interfered with BDNF activation of Akt. Thus, at sublethal concentrations $\mathrm{A} \beta_{1-42}$ interferes with signal transduction at multiple sites. Nevertheless, it seems that the effect of $\mathrm{A} \beta_{1-42}$ is not nonspecific. Not all major signaling pathways were compromised, because the BDNF-induced phosphorylation of PLC $\gamma$ was not affected significantly by the $\mathrm{A} \beta_{1-42}$ treatment.

This is an important observation, because PLC $\gamma$ is activated via direct binding to the autophosphorylated Trk receptors (Huang and Reichardt, 2001), and we observed that $\mathrm{A} \beta_{1-42}$ does not interfere with the BDNF-induced activation of TrkB. In contrast, BDNF activation of the MAPK and PI3-K pathways requires adapter complexes for connection to the activated receptor. We hypothesized, therefore, that $\mathrm{A} \beta_{1-42}$ interferes with BDNF signaling at the level of these docking proteins. This was verified by the observation that $\mathrm{A} \beta_{1-42}$ treatment robustly suppresses the BDNF-stimulated level of Tyr-phosphorylated docking proteins IRS-1 and Shc, which after binding to and being
$\mathbf{B}$

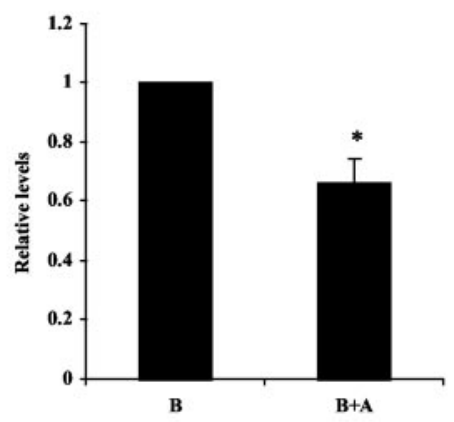

D

IP: She
$-80.9$

$-63.8$

$-37.4$

$-80.9$

$-63.8$

$-37.4$

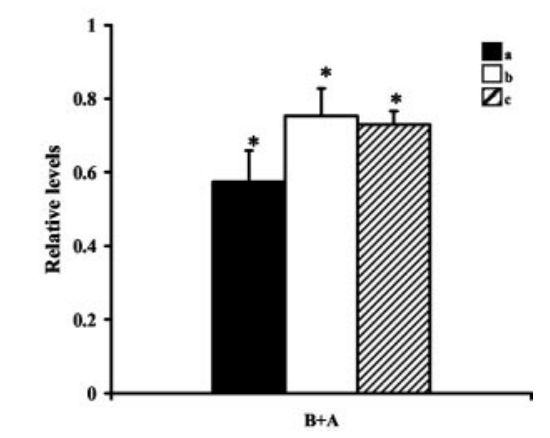

Figure 9. $A \beta_{1-42}$ treatment decreased the level of BDNF-activated IRS-1 and Shc. A, Pretreatment with $10 \mu \mathrm{MA} \beta_{1-42}$ for 2 $\mathrm{hr}$ resulted in a significant reduction in the BDNF-induced increase in Tyr-phosphorylated IRS-1. IRS-1 was immunoprecipitated effects of pretreatment with $10 \mu \mathrm{MA} \beta_{1-42}$. Estimates are the mean \pm SEM $(n=3)$ expressed in terms of phosphorylated P-Shc is oform levels obtained in the BDNF-exposed cultures ( ${ }^{*} p<0.05$, unpaired Student's $t$ test).

phosphorylated by the activated TrkB receptor bind to and activate PI3-K and, via Grb2/SOS, Ras.

In contrast to the present finding of $\mathrm{A} \beta$-induced suppression of the BDNF-elicited activation of the Ras-MAPK pathway, it has been reported that under certain conditions $A \beta$ alone can induce an increase in the basal level of phosphorylated MAPK. Thus, in hippocampal slices $\mathrm{A} \beta_{1-42}$ activates MAPK via coupling to $\alpha 7$ nicotinic acetylcholine receptors (nAChRs) (Dineley et al., 2001). In our cultures no increase in the basal level of phosphorylated ERK or CREB could be detected after exposure to sublethal $\mathrm{A} \beta_{1-42}$ concentrations (Abe and Saito, 2000). Differences in experimental conditions may account for the discrepancy. In the experiments of Dineley et al. (2001) the $A \beta$-induced increase in the level of phosphorylated MAPK was transient, peaking at 5 min; by $2 \mathrm{hr}$, which was the $A \beta$ preincubation time used in our studies, the level of phosphorylated MAPK was restored to that in the untreated preparations. Furthermore, in PC12 and SH-SY5Y neuroblastoma cells, $\mathrm{A} \beta$ results in a modest activation of Akt probably via oxygen-derived free radicals (Martin et al., 2001; Wei et al., 2002). We observed a similar weak effect of the peptide on Akt activity. Nevertheless, the BDNF-induced massive increase in Akt activity was suppressed severely by the $A \beta$ pretreatment, indicating that the mechanisms underlying the effect of $A \beta$ 
$\mathbf{A}$

B
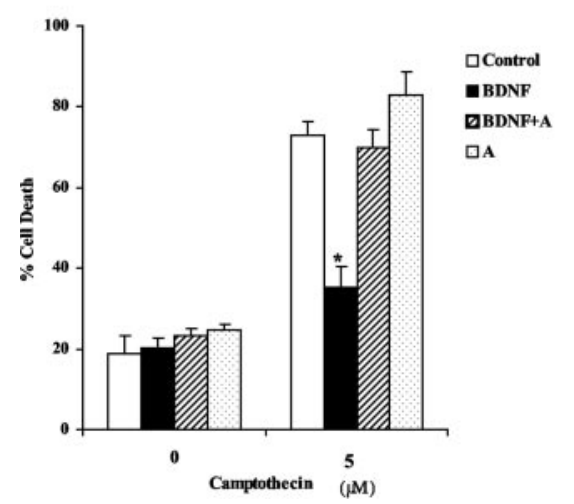

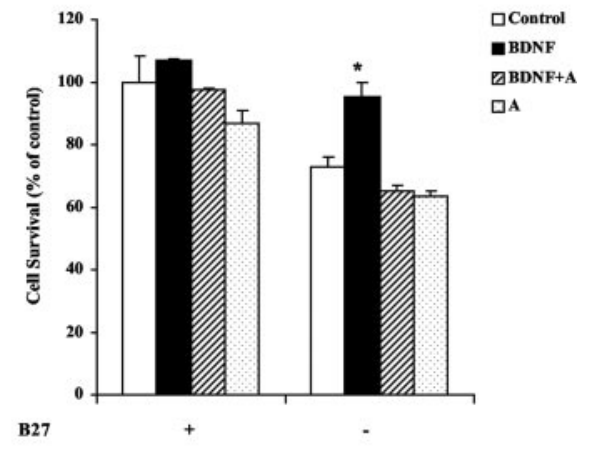

Figure 10. $A \beta_{1-42}$ abrogated BDNF protection of cortical neurons from apoptosis induced either by exposure to camptothecin or by deprivation from trophic support. $A$, Cortical neurons were exposed to $5 \mu \mathrm{m}$ camptothecin for $24 \mathrm{hr}$ to induce apoptosis. Additions: Control, vehicle of BDNF solution; BDNF, $10 \mathrm{ng} / \mathrm{ml} ; \mathrm{BDNF}+\mathrm{A}, 10 \mathrm{ng} / \mathrm{ml} \mathrm{BDNF}+5 \mu \mathrm{mA} \beta_{1-42} ; \mathrm{A}, 5 \mu \mathrm{MA} \beta_{1-42}$. When $\mathrm{A} \beta_{1-42}$ was added, the cultures were preincubated in the presence of the peptide for $1 \mathrm{hr}$. Cell viability was assessed by trypan blue exclusion assay; data are the mean $\pm \operatorname{SE}(n=3) .{ }^{*} p<0.05$ (ANOVA, Fisher's PLSD as the posthoc test). B, The serum-free "trophic" medium B27 was removed from cultures, and after a DMEM wash the cultures were incubated for $36 \mathrm{hr}$ in DMEM in the presence or absence of $10 \mathrm{ng} / \mathrm{ml}$ $\mathrm{BDNF} \pm 5 \mu \mathrm{mA} \beta_{1-42}$. When $\mathrm{A} \beta$ was added, there was $1 \mathrm{hr}$ preincubation period in the presence of $5 \mu \mathrm{mA} \beta_{1-42}$ before the removal of the B27 medium. For comparison, B27 medium was removed from sister cultures but replaced after a DMEM wash with new B27 medium containing the additives as indicated. Cell survival was assayed by MTT assay; data are the mean $\pm \mathrm{SE}(n=3)$. ${ }^{*} p<0.05$ (ANOVA, Fisher's PLSD as the post hoc test).

causing a weak stimulation of Akt and interfering robustly with the massive BDNF activation of Akt are different.

MAPK/ERK activation is involved critically in mechanisms underlying synaptic plasticity, including long-term memory formation via the stimulation of activity-dependent gene expression (Martin et al., 1997; Atkins et al., 1998; Davis et al., 2000). MAPK phosphorylation results in the activation of two parallel signaling routes required for synaptic plasticity-associated transcriptional regulation, namely signaling via MAPK-Rsk2-CREB and MAPK-Elk-1, which target CRE and SRE, respectively, in the promoter regions of the relevant genes (Bonni et al., 1999; Davis et al., 2000). In certain systems PI3-K activation also is required for synaptic plasticity and memory consolidation (Kelly and Lynch, 2000; Lin et al., 2001), and Akt also can activate CREB (Du and Montminy, 1998), which plays an evolutionarily conserved, important role in learning and memory processes (Tully, 1997; Abel and Kandel, 1998). These observations, together with the finding that $\mathrm{A} \beta_{1-42}$ interferes with BDNF-induced transcriptional activity involving the CRE and SRE promoters, are, therefore, consistent with the view that prolonged exposure to sublethal $\mathrm{A} \beta_{1-42}$ concentrations could contribute significantly to the cognitive decline observed in $\mathrm{AD}$ via the suppression of MAPK and PI3-K signaling.

In $\mathrm{AD}$ the neurons degenerate as the disease progresses by mechanisms possibly also involving apoptosis-related processes (Cotman et al., 1999). Activated caspases and accumulation of caspase cleavage products as well as DNA fragmentation have been detected in postmortem $\mathrm{AD}$ brains. These data suggest that, once the $\mathrm{AD}$ brain accumulates insults beyond a critical threshold, an apoptotic pathological cascade is initiated (Cotman et al., 1999). The present study shows the potential functional importance of $\mathrm{A} \beta_{1-42}$ at concentrations at which it does not yet cause degenerative changes, by demonstrating the deleterious effect of the peptide on neuronal vulnerability. Hetman et al. (1999) have established that BDNF is able to prevent cell death triggered by both camptothecin-induced DNA damage via a mechanism involving the activated MAPK pathway and by deprivation from trophic support via a PI3-K-mediated mechanism. We confirmed these observations and found that cell death induced by both camptothecin exposure and deprivation from trophic support is ameliorated by BDNF treatment. However, exposure to sublethal concentrations of $A \beta$, which interferes with the activation of both the MAPK/ERK and the PI3-K pathways, abrogated the effect of BDNF. The increased neuronal vulnerability in the presence of sublethal concentrations of $\mathrm{A} \beta$ may be compounded by the progressive accumulation of other risk factors, including reduced BDNF expression (Phillips et al., 1991; Connor et al., 1997; Ferrer et al., 1999; Tong et al., 2001) and increased DNA damage (Mullaart et al., 1990; Su et al., 1997). Therefore, both reduced BDNF levels and reduced BDNF signaling caused by sublethal $A \beta$ could result, in addition to suppression of synaptic plasticity, in enhanced vulnerability, leading to neuronal dysfunction and, over time, degeneration via apoptosis and other pathways in $\mathrm{AD}$.

In summary, we show that sublethal $\mathrm{A} \beta_{1-42}$ interferes with BDNF signaling by suppressing selectively the activation of the RasMAPK/ERK and PI3-K/Akt pathways and the activation of critical transcription factors, such as CREB and Elk-1 and transcription mediated by these factors, and that sublethal $\mathrm{A} \beta_{1-42}$ increases neuronal vulnerability. These observations, together with our earlier findings, are consistent with the view that sublethal $\mathrm{A} \beta$ may play important roles in $\mathrm{AD}$ pathogenesis before the overt manifestation of the disease by interfering with neuronal functions critical for neuronal maintenance and plasticity.

\section{References}

Abe K, Saito H (2000) Amyloid beta neurotoxicity not mediated by the mitogen-activated protein kinase cascade in cultured rat hippocampal and cortical neurons. Neurosci Lett 292:1-4.

Abel T, Kandel E (1998) Positive and negative regulatory mechanisms that mediate long-term memory storage. Brain Res Brain Res Rev 26:360-378.

Atkins CM, Selcher JC, Petraitis JJ, Trzaskos JM, Sweatt JD (1998) The MAPK cascade is required for mammalian associative learning. Nat Neurosci 1:602-609.

Bonni A, Brunet A, West AE, Datta SR, Takasu MA, Greenberg ME (1999) Cell survival promoted by the Ras-MAPK signaling pathway by transcriptiondependent and -independent mechanisms [comments]. Science 286:1358-1362.

Bourtchuladze R, Frenguelli B, Blendy J, Cioffi D, Schutz G, Silva AJ (1994) Deficient long-term memory in mice with a targeted mutation of the cAMPresponsive element-binding protein. Cell 79:59-68.

Burdick D, Soreghan B, Kwon M, Kosmoski J, Knauer M, Henschen A, Yates J, Cotman C, Glabe C (1992) Assembly and aggregation properties of synthetic Alzheimer's A4/ $\beta$-amyloid peptide analogs. J Biol Chem 267:546-554.

Causing CG, Gloster A, Aloyz R, Bamji SX, Chang E, Fawcett J, Kuchel G, Miller FD (1997) Synaptic innervation density is regulated by neuron-derived BDNF. Neuron 18:257-267.

Chandler LJ, Sutton G, Dorairaj NR, Norwood D (2001) N-methyl D-aspartate receptor-mediated bidirectional control of extracellular signal-regulated kinase activity in cortical neuronal cultures. J Biol Chem 276:2627-2636.

Chapman PF, White GL, Jones MW, Cooper-Blacketer D, Marshall VJ, Irizarry M, Younkin L, Good MA, Bliss TV, Hyman BT, Younkin SG, Hsiao KK (1999) Impaired synaptic plasticity and learning in aged amyloid precursor protein transgenic mice. Nat Neurosci 2:271-276.

Connor B, Young D, Yan Q, Faull RL, Synek B, Dragunow M (1997) Brainderived neurotrophic factor is reduced in Alzheimer's disease. Brain Res Mol Brain Res 49:71-81. 
Cotman CW, Ivins KJ, Anderson AJ (1999) Apoptosis in Alzheimer disease. In: Alzheimer disease, Ed 2 (Terry RD, Katzman R, Bick KL, Sisodia SS, eds), pp 347-358. Philadelphia: Lippincott, Williams and Wilkins.

Datta SR, Brunet A, Greenberg ME (1999) Cellular survival: a play in three Akts. Genes Dev 13:2905-2927.

Davis S, Vanhoutte P, Pages C, Caboche J, Laroche S (2000) The MAPK/ERK cascade targets both elk-1 and cAMP response element-binding protein to control long-term potentiation-dependent gene expression in the dentate gyrus in vivo. J Neurosci 20:4563-4572.

Deisseroth K, Heist EK, Tsien RW (1998) Translocation of calmodulin to the nucleus supports CREB phosphorylation in hippocampal neurons. Nature 392:198-202.

Dineley KT, Westerman M, Bui D, Bell K, Ashe KH, Sweatt JD (2001) $\beta$-Amyloid activates the mitogen-activated protein kinase cascade via hippocampal $\alpha 7$ nicotinic acetylcholine receptors: in vitro and in vivo mechanisms related to Alzheimer's disease. J Neurosci 21:4125-4133.

Du K, Montminy M (1998) CREB is a regulatory target for the protein kinase Akt/PKB. J Biol Chem 273:32377-32379.

Ferrer I, Marin C, Rey MJ, Ribalta T, Goutan E, Blanco R, Tolosa E, Marti E (1999) BDNF and full-length and truncated TrkB expression in Alzheimer disease. Implications in therapeutic strategies. J Neuropathol Exp Neurol 58:729-739.

Finkbeiner S, Tavazoie SF, Maloratsky A, Jacobs KM, Harris KM, Greenberg ME (1997) CREB: a major mediator of neuronal neurotrophin responses. Neuron 19:1031-1047.

Hardy J, Selkoe DJ (2002) The amyloid hypothesis of Alzheimer's disease: progress and problems on the road to therapeutics. Science 297:353-356.

Hetman M, Kanning K, Cavanaugh JE, Xia Z (1999) Neuroprotection by brainderived neurotrophic factor is mediated by extracellular signal-regulated kinase and phosphatidylinositol 3-kinase. J Biol Chem 274:22569-22580.

Holcomb L, Gordon MN, McGowan E, Yu X, Benkovic S, Jantzen P, Wright K, Saad I, Mueller R, Morgan D, Sanders S, Zehr C, O’Campo K, Hardy J, Prada CM, Eckman C, Younkin S, Hsiao K, DuffK (1998) Accelerated Alzheimertype phenotype in transgenic mice carrying both mutant amyloid precursor protein and presenilin 1 transgenes. Nat Med 4:97-100.

Hsia AY, Masliah E, McConlogue L, Yu GQ, Tatsuno G, Hu K, Kholodenko D, Malenka RC, Nicoll RA, Mucke L (1999) Plaque-independent disruption of neural circuits in Alzheimer's disease mouse models. Proc Natl Acad Sci USA 96:3228-3233.

Hsiao K, Chapman P, Nilsen S, Eckman C, Harigaya Y, Younkin S, Yang F, Cole G (1996) Correlative memory deficits, $A \beta$ elevation, and amyloid plaques in transgenic mice [comments]. Science 274:99-102.

Huang EJ, Reichardt LF (2001) Neurotrophins: roles in neuronal development and function. Annu Rev Neurosci 24:677-736.

Iida N, Namikawa K, Kiyama H, Ueno H, Nakamura S, Hattori S (2001) Requirement of Ras for the activation of mitogen-activated protein kinase by calcium influx, cAMP, and neurotrophin in hippocampal neurons. J Neurosci 21:6459-6466.

Ivins KJ, Thornton PL, Rohn TT, Cotman CW (1999) Neuronal apoptosis induced by $\beta$-amyloid is mediated by caspase- 8 . Neurobiol Dis 6:440 -449 .

Kelly A, Lynch MA (2000) Long-term potentiation in dentate gyrus of the rat is inhibited by the phosphoinositide 3-kinase inhibitor, wortmannin. Neuropharmacology 39:643-651.

Korte M, Carroll P, Wolf E, Brem G, Thoenen H, Bonhoeffer T (1995) Hippocampal long-term potentiation is impaired in mice lacking brain-derived neurotrophic factor. Proc Natl Acad Sci USA 92:8856-8860.

Lambert MP, Barlow AK, Chromy BA, Edwards C, Freed R, Liosatos M, Morgan TE, Rozovsky I, Trommer B, Viola KL, Wals P, Zhang C, Finch CE, Krafft GA, Klein WL (1998) Diffusible, nonfibrillar ligands derived from $\mathrm{A} \beta_{1-42}$ are potent central nervous system neurotoxins. Proc Natl Acad Sci USA 95:6448-6453.

Li YX, Zhang Y, Lester HA, Schuman EM, Davidson N (1998) Enhancement of neurotransmitter release induced by brain-derived neurotrophic factor in cultured hippocampal neurons. J Neurosci 18:10231-10240.

Lin CH, Yeh SH, Lu KT, Leu TH, Chang WC, Gean PW (2001) A role for the PI-3 kinase signaling pathway in fear conditioning and synaptic plasticity in the amygdala. Neuron 31:841-851.

Lue LF, Kuo YM, Roher AE, Brachova L, Shen Y, Sue L, Beach T, Kurth JH, Rydel RE, Rogers J (1999) Soluble amyloid beta peptide concentration as a predictor of synaptic change in Alzheimer's disease. Am J Pathol 155:853-862.

Marshall CJ (1994) MAP kinase kinase kinase, MAP kinase kinase and MAP kinase. Curr Opin Genet Dev 4:82-89.
Martin D, Salinas M, Lopez-Valdaliso R, Serrano E, Recuero M, Cuadrado A (2001) Effect of the Alzheimer amyloid fragment $\mathrm{A} \beta_{25-35}$ on Akt/PKB kinase and survival of PC12 cells. J Neurochem 78:1000-1008.

Martin KC, Michael D, Rose JC, Barad M, Casadio A, Zhu H, Kandel ER (1997) MAP kinase translocates into the nucleus of the presynaptic cell and is required for long-term facilitation in Aplysia. Neuron 18:899-912.

Martin SJ, Reutelingsperger CP, McGahon AJ, Rader JA, van Schie RC, LaFace DM, Green DR (1995) Early redistribution of plasma membrane phosphatidylserine is a general feature of apoptosis regardless of the initiating stimulus: inhibition by overexpression of Bcl-2 and Abl. J Exp Med 182:1545-1556.

Martinez A, Alcantara S, Borrell V, Del Rio JA, Blasi J, Otal R, Campos N, Boronat A, Barbacid M, Silos-Santiago I, Soriano E (1998) TrkB and TrkC signaling are required for maturation and synaptogenesis of hippocampal connections. J Neurosci 18:7336-7350.

Minichiello L, Korte M, Wolfer D, Kuhn R, Unsicker K, Cestari V, Rossi-Arnaud C, Lipp HP, Bonhoeffer T, Klein R (1999) Essential role for TrkB receptors in hippocampus-mediated learning. Neuron 24:401-414.

Morris EJ, Geller HM (1996) Induction of neuronal apoptosis by camptothecin, an inhibitor of DNA topoisomerase-I: evidence for cell cycleindependent toxicity. J Cell Biol 134:757-770.

Morris JC, Storandt M, McKeel Jr DW, Rubin EH, Price JL, Grant EA, Berg L (1996) Cerebral amyloid deposition and diffuse plaques in "normal" aging: evidence for presymptomatic and very mild Alzheimer's disease. Neurology 46:707-719.

Mullaart E, Boerrigter ME, Ravid R, Swaab DF, Vijg J (1990) Increased levels of DNA breaks in cerebral cortex of Alzheimer's disease patients. Neurobiol Aging 11:169-173.

Myers SJ, Peters J, Huang Y, Comer MB, Barthel F, Dingledine R (1998) Transcriptional regulation of the GluR2 gene: neural-specific expression, multiple promoters, and regulatory elements. J Neurosci 18:6723-6739.

Naslund J, Haroutunian V, Mohs R, Davis KL, Davies P, Greengard P, Buxbaum JD (2000) Correlation between elevated levels of amyloid $\beta$-peptide in the brain and cognitive decline [comments]. JAMA 283:1571-1577.

Numakawa T, Matsumoto T, Adachi N, Yokomaku D, Kojima M, Takei N, Hatanaka H (2001) Brain-derived neurotrophic factor triggers a rapid glutamate release through increase of intracellular $\mathrm{Ca}^{2+}$ and $\mathrm{Na}^{+}$in cultured cerebellar neurons. J Neurosci Res 66:96-108.

Oda T, Wals P, Osterburg HH, Johnson SA, Pasinetti GM, Morgan TE, Rozovsky I, Stine WB, Snyder SW, Holzman TF, Krafft GA, Finch CE (1995) Clusterin (apoJ) alters the aggregation of amyloid $\beta$-peptide $\left(\mathrm{A} \beta_{1-42}\right)$ and forms slowly sedimenting $A \beta$ complexes that cause oxidative stress. Exp Neurol 136:22-31.

Patterson SL, Abel T, Deuel TA, Martin KC, Rose JC, Kandel ER (1996) Recombinant BDNF rescues deficits in basal synaptic transmission and hippocampal LTP in BDNF knockout mice. Neuron 16:1137-1145.

Phillips HS, Hains JM, Armanini M, Laramee GR, Johnson SA, Winslow JW (1991) BDNF mRNA is decreased in the hippocampus of individuals with Alzheimer's disease. Neuron 7:695-702.

Pike CJ, Burdick D, Walencewicz AJ, Glabe CG, Cotman CW (1993) Neurodegeneration induced by $\beta$-amyloid peptides in vitro: the role of peptide assembly state. J Neurosci 13:1676-1687.

Selkoe DJ (1999) Biology of $\beta$-amyloid precursor protein and the mechanism of Alzheimer disease. In: Alzheimer disease, Ed 2 (Terry RD, Katzman R, Bick KL, Sisodia SS, eds), pp 293-310. Philadelphia: Lippincott, Williams and Wilkins.

Shieh PB, Hu SC, Bobb K, Timmusk T, Ghosh A (1998) Identification of a signaling pathway involved in calcium regulation of BDNF expression. Neuron 20:727-740.

Snowdon DA, Greiner LH, Markesbery WR (2000) Linguistic ability in early life and the neuropathology of Alzheimer's disease and cerebrovascular disease. Findings from the Nun study. Ann NY Acad Sci 903:34-38.

Su JH, Deng G, Cotman CW (1997) Bax protein expression is increased in Alzheimer's brain: correlations with DNA damage, Bcl-2 expression, and brain pathology. J Neuropathol Exp Neurol 56:86-93.

Sweatt JD (2001) The neuronal MAP kinase cascade: a biochemical signal integration system subserving synaptic plasticity and memory. J Neurochem 76:1-10.

Tao X, Finkbeiner S, Arnold DB, Shaywitz AJ, Greenberg ME (1998) $\mathrm{Ca}^{2+}$ influx regulates BDNF transcription by a CREB family transcription factordependent mechanism. Neuron [Erratum (1998) 20:1297] 20:709-726. 
Thoenen H (2000) Neurotrophins and activity-dependent plasticity. Prog Brain Res 128:183-191.

Tong L, Thornton PL, Balazs R, Cotman CW (2001) $\beta$-Amyloid - $-42_{2}$ impairs activity-dependent cAMP-response element-binding protein signaling in neurons at concentrations in which cell survival is not compromised. J Biol Chem 276:17301-17306.

Tully T (1997) Regulation of gene expression and its role in long-term memory and synaptic plasticity. Proc Natl Acad Sci USA 94:4239-4241.

Vitolo OV, Sant'Angelo A, Costanzo V, Battaglia F, Arancio O, Shelanski M (2002) Amyloid $\beta$-peptide inhibition of the PKA/CREB pathway and longterm potentiation: reversibility by drugs that enhance cAMP signaling. Proc Natl Acad Sci USA 99:13217-13221.
Walsh DM, Klyubin I, Fadeeva JV, Cullen WK, Anwyl R, Wolfe MS, Rowan MJ, Selkoe DJ (2002) Naturally secreted oligomers of amyloid beta protein potently inhibit hippocampal long-term potentiation in vivo. Nature 416:535-539.

Wasylyk B, Hagman J, Gutierrez-Hartmann A (1998) Ets transcription factors: nuclear effectors of the Ras-MAP-kinase signaling pathway. Trends Biochem Sci 23:213-216.

Wei W, Wang X, Kusiak JW (2002) Signaling events in amyloid $\beta$-peptideinduced neuronal death and insulin-like growth factor I protection. J Biol Chem 277:17649-17656.

Yankner BA (1996) Mechanisms of neuronal degeneration in Alzheimer's disease. Neuron 16:921-932. 